\title{
Food Restriction Increases Glutamate Receptor-Mediated Burst Firing of Dopamine Neurons
}

\author{
Sarah Y. Branch, ${ }^{1}$ R. Brandon Goertz, ${ }^{3}$ Amanda L. Sharpe,${ }^{5}$ Janie Pierce, ${ }^{3}$ Sudip Roy, ${ }^{3}$ Daijin Ko, ${ }^{4}$ Carlos A. Paladini, ${ }^{3}$ \\ and Michael J. Beckstead ${ }^{1,2}$ \\ ${ }^{1}$ Department of Physiology, and ${ }^{2}$ Center for Biomedical Neuroscience, University of Texas Health Science Center, San Antonio, Texas 78229, ${ }^{3}$ UTSA \\ Neurosciences Institute, and ${ }^{4}$ Department of Management Science and Statistics, University of Texas at San Antonio, San Antonio, Texas 78249 , and ${ }^{5}$ Feik \\ School of Pharmacy, University of the Incarnate Word, San Antonio, Texas 78209
}

Restriction of food intake increases the acquisition of drug abuse behavior and enhances the reinforcing efficacy of those drugs. However, the neurophysiological mechanisms responsible for the interactions between feeding state and drug use are largely unknown. Here we show that chronic mild food restriction increases the burst firing of dopamine neurons in the substantia nigra. Dopamine neurons from food-restricted mice exhibited increased burst firing in vivo, an effect that was enhanced by an injection of the psychomotor stimulant cocaine $(10 \mathrm{mg} / \mathrm{kg}$, i.p.). Food restriction also enhanced aspartic acid-induced burst firing of dopamine neurons in an $e x v i v o$ brain slice preparation, consistent with an adaptation occurring in the somatodendritic compartment and independent of a circuit mechanism. Enhanced burst firing persisted after $10 \mathrm{~d}$ of free feeding following chronic food restriction but was not observed following a single overnight fast. Whole-cell patch-clamp recordings indicated that food restriction also increased electrically evoked AMPAR/NMDAR ratios and increased D2 autoreceptor-mediated desensitization in dopamine neurons. These results identify dopamine neurons in the substantia nigra as a convergence point for the interactions between feeding state and drugs of abuse. Furthermore, increased glutamate transmission combined with decreased autoreceptor inhibition could work in concert to enhance drug efficacy in response to food restriction.

\section{Introduction}

Addiction and substance abuse are characterized by alterations in the brain's endogenous reward circuitry, and a complex behavioral relationship exists between feeding state and drug intake. In rodents, food restriction (FR) increases self-administration of most, if not all, major classes of abused drugs (Carroll et al., 1979; de la Garza et al., 1981; Carroll and Meisch, 1984, Carroll, 1985; de la Garza and Johanson, 1987; Macenski and Meisch, 1999; Shalev et al., 2000, 2003). Many laboratories studying drug selfadministration use food restriction to enhance motivational states and to increase the speed and reliability with which rodents learn to respond for drugs.

Since both feeding and abused drugs increase extracellular dopamine (DA) concentrations in terminal regions (Di Chiara and Imperato, 1988; Brown et al., 2011), DA neurons in the ventral midbrain could be responsible for food restriction-induced increases in drug reinforcement. In the nucleus accumbens, food

\footnotetext{
Received Oct. 31, 2012; revised July 16, 2013; accepted July 20, 2013.

Author contributions: A.L.S., C.A.P., and M.J.B. designed research;S.Y.B., R.B.G., J.P., S.R., and M.J.B. performed research; S.Y.B., R.B.G., D.K., and M.J.B. analyzed data; S.Y.B., R.B.G., C.A.P., and M.J.B. wrote the paper.

This work was funded by the National Institutes of Health through K01 (DA21699) and R01 Awards (DA32701) to M.J.B., and R01 Awards (MH79276 and DA30530) to C.A.P. Additional funding was provided by a grant from the Research Enhancement Fund through the San Antonio Life Sciences Institute (to M.J.B. and C.A.P.) and American Heart Association National Scientist Development Grant SDG4350066 (to A.L.S.). We thank Joshua D. Klaus for technical support.

Correspondence should be addressed to Michael J. Beckstead, Department of Physiology, University of Texas Health ScienceCenter at San Antonio, 7703 Floyd Curl Drive, San Antonio, TX78229. E-mail: beckstead@uthscsa.edu. DOI:10.1523/JNEUROSCI.5099-12.2013

Copyright $\odot 2013$ the authors $\quad 0270-6474 / 13 / 3313861-12 \$ 15.00 / 0$
}

restriction augments the increase in DA produced by cocaine and amphetamine, indicating that cellular changes may occur that sensitize DA cells to the rewarding properties of abused drugs (Pothos et al., 1995; Rougé-Pont et al., 1995; Stuber et al., 2002; Cadoni et al., 2003). Food restriction also decreases DA transporter (DAT)-mediated DA uptake (Zhen et al., 2006; Sevak et al., 2008), increases DA receptor protein and mRNA levels in the striatum (Lindblom et al., 2006; Thanos et al., 2008), and augments the locomotor effects of DA receptor agonists (Carr et al., 2001, 2003). Food restriction-induced increases in terminal DA function could thus nonselectively increase the reinforcing properties of DA-releasing stimuli, including drugs of abuse.

In vivo, DA neurons fire bursts of action potentials that are driven by glutamatergic signaling but are heavily influenced by inhibitory input and intrinsic conductances (Grace and Bunney, 1984; Overton and Clark, 1997; Wolfart and Roeper, 2002; Mathon et al., 2003; Blythe et al., 2009; Zweifel et al., 2009; Lobb et al., 2011). Bursting facilitates the release of DA in terminal fields, overwhelming uptake transporters and producing a supra-additive phasic response (Gonon, 1988; Suaud-Chagny et al., 1992; Chergui et al., 1994; Cooper, 2002; Heien and Wightman, 2006). This transient rise in DA has been strongly implicated in error prediction and reward seeking (Phillips et al., 2003; Roitman et al., 2004; Schultz, 2006; Wanat et al., 2009; Zweifel et al., 2009). Thus, any manipulation that increases DA neuron bursting could influence the behavioral consequences of phasic DA release.

To investigate the interaction between feeding state and drug abuse, we hypothesized that chronic food restriction increases 
substantia nigra DA neuron excitability. Our findings indicate that DA neurons from food-restricted mice exhibit increased burst firing, AMPAR/NMDAR ratios, and desensitization of D2 autoreceptors when compared with ad libitum-fed controls (AL mice). We also found that cocaine further increases burst firing only in food-restricted mice. The results identify substantia nigra DA neurons as a convergence point for the relationship between feeding state and drug abuse, and suggest that alterations to both glutamate and dopamine receptor signaling may contribute to the behavioral consequences of food restriction.

\section{Materials and Methods}

\section{Animals and food restriction protocol}

Animal procedures were approved a priori by the Institutional Care and Use Committees at the University of Texas Health Science Center at San Antonio and the University of Texas at San Antonio. Eight-week-old male DBA/2J mice (Jackson Laboratories) were singly housed for a minimum of $4 \mathrm{~d}$ before the start of the study and provided with cotton nesting material (Shred-A-Bed, Novalek) to decrease the stress of individual housing. Mice were separated into two groups balanced for initial body weight and were either fed ad libitum (AL mice) or placed on food restriction (FR mice). Animals were kept on a 14/10 light/dark cycle (lights out at 7:00 P.M.) and were weighed daily near the end of the light cycle (5:00 P.M.). FR mice were restricted to criteria ( $80-85 \%$ of their initial body weight) by administering one daily feeding (usually $2.3-3.0$ g) of standard rodent chow immediately after being weighed. This procedure resulted in the mice achieving criteria in $\sim 10 \mathrm{~d}$, after which time the size of their daily meal was titrated to stably maintain the mice at their reduced body weight for a minimum of $5 \mathrm{~d}$ before experimentation. Two additional groups of mice were added later. Re-fed mice were food restricted to the $80-85 \%$ criteria, stably maintained at the reduced weight for $10 \mathrm{~d}$, then re-fed ad libitum for $10 \mathrm{~d}$ before recording. Acutely foodrestricted mice were singly housed with ad libitum access to food for at least $5 \mathrm{~d}$, at which time their food was removed overnight and experiments were performed the following day.

\section{In vivo electrophysiology}

Mice were anesthetized with urethane $(1.8 \mathrm{~g} / \mathrm{kg})$ through intraperitoneal injections and installed into a stereotaxic frame. The incision site and points of contact with the apparatus were treated with $2 \%$ lidocaine ointment. Body temperature was maintained at $37^{\circ} \mathrm{C}$ by a heating pad. An incision in the scalp was made to expose the skull overlying the midbrain, and small holes were drilled above the substantia nigra pars compacta (relative to Bregma (in $\mathrm{mm}$ ): anterior, -5.0 ; lateral, 1.0/-1.0; ventral, -6.5 to -8.0 ) for insertion of a recording electrode. Recording electrodes were constructed from borosilicate glass capillary tubing (World Precision Instruments) with a $1.5 \mathrm{~mm}$ outer diameter, were pulled on a Model P-97 Flaming/Brown horizontal pipette puller (Sutter Instruments), and were filled with $1 \mathrm{M} \mathrm{NaCl}$. The recordings were amplified with a 2400A extracellular amplifier (Dagan) and recorded using Chart Pro (AD Instruments). The amplifier filter settings were set with a low-frequency cutoff of $100 \mathrm{~Hz}$ and a high-frequency cutoff of $10 \mathrm{kHz}$. Dopaminergic neurons were identified by the following criteria: a slow firing rate $(<10$ spikes/s); and an extracellular waveform duration of $>1.1 \mathrm{~ms}$ from the onset of the spike to the negative trough. Dopaminergic neurons were recorded for $20 \mathrm{~min}$ before the administration of cocaine $(10 \mathrm{mg} / \mathrm{kg})$ by intraperitoneal injection. Five minutes after the injection of cocaine, recordings were resumed for $10 \mathrm{~min}$. At the end of some experiments, recording sites were marked with the injection of pontamine sky blue for confirmation of correct anatomical localization. Bursts were detected using the Robust Gaussian Surprise (RGS) method, which was recently described by Ko et al. (2012).

\section{Brain slice electrophysiology}

On the day of the experiment, mice were anesthetized with isoflurane and killed by rapid decapitation. Brains were harvested in ice-cold oxygenated Krebs' solution containing the following (in mM): $126 \mathrm{NaCl}, 2.5 \mathrm{KCl}$, $1.2 \mathrm{MgCl}_{2}, 2.4 \mathrm{CaCl}_{2}, 0.25 \mathrm{NaH}_{2} \mathrm{PO}_{4}, 25 \mathrm{NaHCO}_{3}$, and $11 \mathrm{D}$-glucose, plus
1 kynurenic acid. Horizontal slices of midbrain (180-200 $\mu \mathrm{m}$ thick) were obtained with a vibrating microtome (Leica Microsystems), incubated at $34^{\circ} \mathrm{C}$ for $30 \mathrm{~min}$, and maintained afterward at room temperature.

Slices were placed into a chamber attached to an upright microscope and perfused at $\sim 2 \mathrm{ml} / \mathrm{min}$ in $34^{\circ} \mathrm{C}$ Krebs' solution. DA cells of the substantia nigra were visually identified by location compared with the medial terminal nucleus of the accessory optic tract, the interpeduncular fossa and the medial lemniscus (Ford et al., 2006). Cells were also tested for the presence of a hyperpolarization-induced $I(h)$ current (for wholecell experiments) and spontaneous rhythmic firing of wide extracellular waveforms (>1.1 ms; Beckstead et al., 2009). Firing was monitored in the loose cell-attached configuration using glass electrodes (5-10 $\mathrm{M} \Omega$ resistance) filled with Na HEPES plus $20 \mathrm{~mm} \mathrm{NaCl}$, pH 7.40, $290 \mathrm{mOsm} / \mathrm{L}$ (Branch and Beckstead, 2012). Whole-cell recordings were obtained using microelectrodes (2-5 $\mathrm{M} \Omega$ resistance) filled with an internal solution of (in mM) $115 \mathrm{~K}$-methyl sulfate, $20 \mathrm{NaCl}, 1.5 \mathrm{MgCl}_{2}, 0.4$ EGTA, 10 HEPES, 2 ATP, and 0.4 GTP, and adjusted to a pH of 7.35-7.40, 270-275 $\mathrm{mOsm} / \mathrm{L}$. For the aspartate iontophoresis experiment, the NMDA receptor coagonist glycine $(10 \mu \mathrm{M})$ was added to the Krebs' solution. For the AMPAR/NMDAR ratio experiment, $\mathrm{CsCl}$ was substituted for $\mathrm{K}$-methyl sulfate in the pipette solution, and glutamate receptor-mediated EPSCs were isolated by the addition of glycine $(10 \mu \mathrm{M})$ and the pharmacological receptor blockers picrotoxin $\left(100 \mu \mathrm{M}, \mathrm{GABA}_{\mathrm{A}}\right)$, CGP 55845 (100 nM, $\mathrm{GABA}_{\mathrm{B}}$ ), hexamethonium (100 $\mu \mathrm{M}$, nicotinic acetylcholine), and sulpiride (200 nM, DA D2). Stimulation was performed with a bipolar platinum-stimulating electrode (FHC) that was placed into the slice just caudal to the cell being recorded.

\section{Drugs}

DA ( $1 \mathrm{M})$ and aspartic acid ( $800 \mathrm{~mm})$ were applied by iontophoresis (Dagan Instruments). Iontophoretic pipettes were pulled using thinwalled glass microelectrodes (resistance, $\sim 100 \mathrm{M} \Omega$ ). For DA iontophoresis, the tip of the electrode was placed $\sim 10 \mu \mathrm{m}$ caudal of the soma, and DA was ejected as a cation with a pulse of $200 \mathrm{nA}$. D2 autoreceptormediated outward currents produced by DA iontophoresis were monitored in real time. The amplitude typically plateaued in $2-3 \mathrm{~s}$, indicating that a maximally effective pulse had been achieved. A backing current of -25 to $45 \mathrm{nA}$ was applied between ejections to prevent passive leakage. For aspartate iontophoresis, the electrode was aimed at a major visible dendrite and aspartate was ejected as an anion with a pulse of $-200 \mathrm{nA}$. A backing current of 1-6 nA was applied between ejections to prevent passive leakage. If an initial test ejection of aspartate $(100 \mathrm{~ms})$ did not rapidly evoke at least three spikes in the neuron being recorded, the pipette was repositioned at a different visible dendrite. Aspartic acid iontophoretic pulses of 40-200 ms were used to evoke firing in experiments.

Cocaine hydrochloride was a generous gift from the National Institute on Drug Abuse drug supply program (Bethesda, MD). DA hydrochloride, picrotoxin, hexamethonium, DNQX, sulpiride, D-aspartic acid, $\mathrm{Mg}$ ATP, Na GTP, Na HEPES, K HEPES, and EGTA were obtained from Sigma-Aldrich. CGP 55845 was obtained from Tocris Bioscience, K-methyl sulfate was from Acros Organics, isoflurane was from Baxter, and glycine was from Research Products International.

\section{Statistical analyses}

In vivo study. A two-way repeated-measures ANOVA (RMANOVA) with subject effect was used to analyze the bursts per minute and background firing frequencies. Between-group tests were used to evaluate the effect of diet, while within-subject tests were used to analyze cocaine treatment and the interaction between diet and cocaine treatment. Paired $t$ tests were performed subsequent to significant RMANOVAs to make comparisons between the cocaine and control treatments in each of the FR and AL groups. Welch's two-sample $t$ tests were used to compare individual groups and to confirm the significant interaction between diet and cocaine. All statistical analyses were performed using the statistics program R (www.r-project.org). Summary data are presented as the mean \pm SE, with threshold significance $(\alpha)$ set to 0.05 .

Ex vivo study. One-way and two-way ANOVAs were used to analyze ex vivo data (Prism, GraphPad). Within-cell designs (RMANOVAs) were used wherever feasible, but this was sometimes precluded by missing data 
A

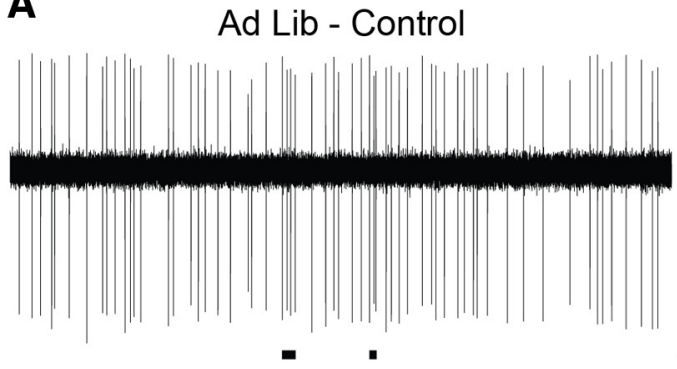

Ad Lib - Cocaine $(10 \mathrm{mg} / \mathrm{kg})$

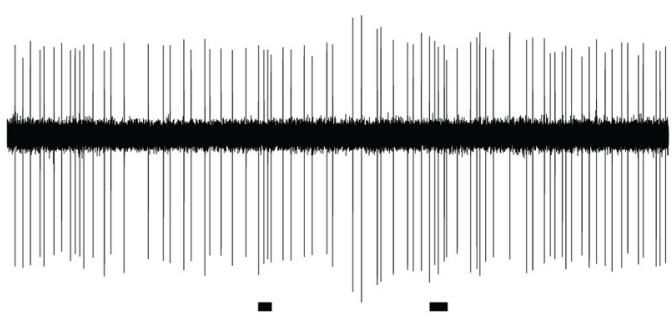

c

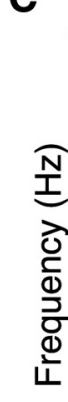$$
\text { Background firing frequency }
$$

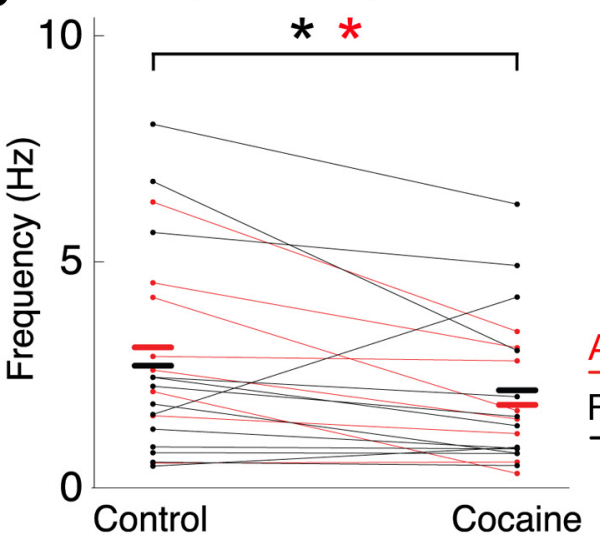

B

Food Restricted - Control

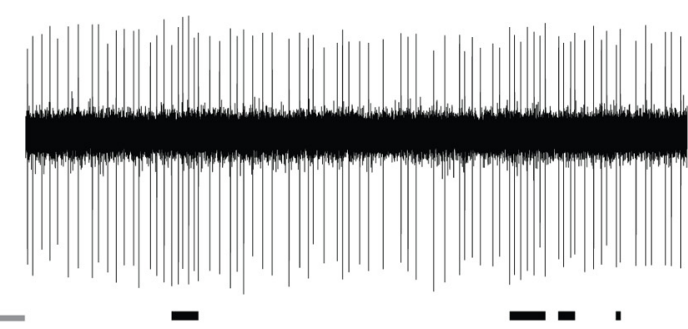

$5 s$

Food Restricted - Cocaine $(10 \mathrm{mg} / \mathrm{kg}$ )

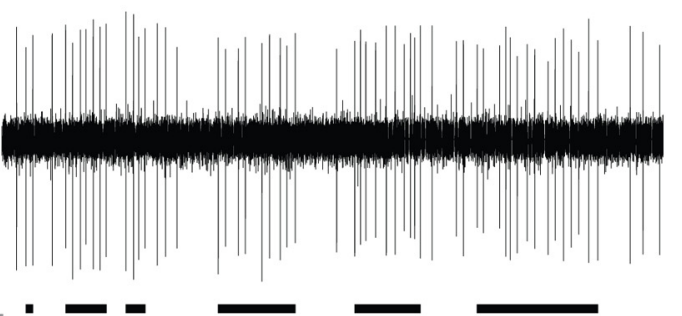

$5 \mathrm{~s}$

D

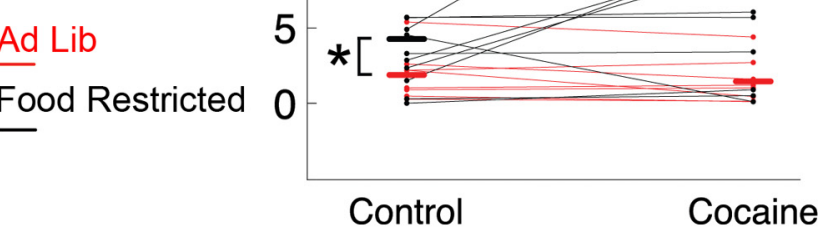

Figure 1. Effects of cocaine on background and burst-firing rates in ad libitum-fed and food-restricted mice. $A, B$, Single-unit extracellular recordings of DA neurons were established in ad libitum $(\boldsymbol{A})$ and food-restricted ( $\boldsymbol{B})$ mice for $20 \mathrm{~min}$. Cocaine (10 mg/kg, i.p.) was administered, and $5 \mathrm{~min}$ later recordings were resumed for a duration of 10 min. Burst events are marked by black horizontal bars. C, Summarized data indicated no difference in background firing rate between groups. However, cocaine did produce a decrease in firing rate in AL mice (indicated by red asterisk) as well as FR mice (indicated by black asterisk). D, Burst-firing analysis indicated that under control conditions neurons in food-restricted mice exhibited a greater number of bursts per minute than ad libitum mice (indicated by black asterisk on left). Cocaine significantly increased the number of bursts per minute in the food-restricted mice (indicated by black asterisk on top) but not in ad libitum mice. Ad Lib, ad libitum.

points (in physiological analyses of interspike interval and pause length). In each experiment that used aspartic acid, we observed a significant main effect of iontophoretic pulse length, which is presented once in the Results and thereafter excluded for brevity. The Sidak multiplecomparisons test was used to compare single means across groups of mice as a post hoc analysis following significant ANOVA interaction terms and as a descriptive measure when the null hypothesis (of no interaction) was not rejected. Gehan-Breslow-Wilcoxon $\chi^{2}$ analyses were used to compare burst sensitivity between groups. Student's $t$ tests were performed when absolutely necessary. Data are presented as the mean \pm SE. In all cases, $\alpha$ was set a priori at 0.05 .

\section{Results}

We investigated whether DA neuron excitability in the substantia nigra is enhanced by prolonged mild dietary restriction. AL mice were given free access to regular rodent chow, while FR mice were reduced to $80-85 \%$ of their initial body weight and maintained there for a minimum of $5 \mathrm{~d}$ before experiments were conducted. The mean weights of the mice taken before they were killed was $27.0 \pm 0.51 \mathrm{~g}$ for the AL group and $20.7 \pm 0.35 \mathrm{~g}$ for the FR group.

\section{In vivo electrophysiological recordings}

To address the effects of food restriction on dopaminergic firing patterns, in vivo single-unit recordings were conducted on midbrain dopaminergic neurons from anesthetized animals. Neurons were recorded from four $\mathrm{AL}$ and five $\mathrm{FR}$ mice. All dopaminergic neurons were identified by electrophysiological criteria including their slow spontaneous firing rates $(<10$ spikes/s), a waveform duration of $>1.1 \mathrm{~ms}$ from the onset of the spike to the negative trough (Ungless et al., 2004), and overall firing pattern (Grace and Bunney, 1984; Marinelli et al., 2006). Dopaminergic neurons were recorded for $20 \mathrm{~min}$ before cocaine was administered by intraperitoneal injection $(10 \mathrm{mg} / \mathrm{kg})$. Five minutes after the injection of cocaine, the recordings were resumed for $10 \mathrm{~min}$. DA neurons in the AL mice had a background firing frequency of $3.1 \pm 0.65 \mathrm{~Hz}(n=8$; Fig. $1 A, C)$ that was not significantly different from neurons in FR mice $(2.7 \pm 0.69 \mathrm{~Hz}$, $n=13$; two-sample $t$ test, $p=0.67$; Fig. $1 B, C)$. Two-way RMANOVA analysis indicated that intraperitoneal injection of 
the psychomotor stimulant and DAT inhibitor cocaine $(10 \mathrm{mg} /$ $\mathrm{kg})$ produced a significant decrease in firing rate $\left(F_{(1,19)}=8.3448\right.$, $p=0.009)$; however, there was no main effect of diet $\left(F_{(1,19)}=\right.$ $0.0024, p=0.96)$ and no significant diet-cocaine interaction $\left(F_{(1,19)}=1.5571, p=0.23\right)$. This suggests that cocaine decreases the mean firing rate of dopamine neurons independent of whether the mice have been food restricted.

Food restriction significantly increased the mean number of bursts per minute compared with AL mice (Fig. 1D; FR group, $4.27 \pm 0.80$ bursts/min, $n=12$; AL group, $1.88 \pm 0.59$ bursts/ min, $n=8$; two-sample $t$ test, $\left.t_{(19)}=2.19, p=0.04\right)$. Two-way RMANOVA analysis on the burst frequency of DA neurons indicated a significant main effect of diet $\left(F_{(1,19)}=8.36, p=0.009\right)$ and cocaine $\left(F_{(1,19)}=4.92, p=0.04\right)$, as well as a significant diet-cocaine interaction $\left(F_{(1,19)}=4.33, p=0.05\right)$. Analysis of individual groups indicated that cocaine had no effect on the burst activity in AL mice (control, $1.88 \pm 0.59$ bursts/min; cocaine, $1.45 \pm 0.52$ bursts $/ \mathrm{min} ; n=8$; paired $t$ test, $t_{(7)}=-1.6$, $p=0.15$ ) but did increase burst activity in FR mice (control, $4.27 \pm 0.80 \mathrm{bursts} / \mathrm{min}$; cocaine, $8.10 \pm 1.83$ bursts $/ \mathrm{min} ; n=12$; $\left.t_{(12)}=2.4, p<0.05\right)$. The mean number of spikes per burst was similar in cells from AL and FR mice $(3.58 \pm 0.31$ and $3.34 \pm$ $0.46, n=8$ and 12, respectively; Welch's two-sample $t$ test, $\left.t_{(17.5)}=-0.43, p=0.67\right)$. One cell did not exhibit any bursts and was thus excluded from the spike number analysis. Two-way RMANOVA analysis of mean burst size indicated no main effect of diet $\left(F_{(1,18)}=0.98, p=0.34\right)$ or cocaine treatment $\left(F_{(1,18)}=\right.$ $0.03, p=0.87)$ and no significant diet-cocaine interaction $\left(F_{(1,18)}=0.68, p=0.42\right)$. Therefore, while food restriction does not affect the background firing frequency of dopaminergic neurons or the number of spikes per burst, it does significantly increase the number of bursts per minute. Cocaine administration increases the number of bursts per minute in FR mice, an effect that is not observed in AL mice.

\section{Ex vivo electrophysiological recordings}

To determine whether the food restriction-induced enhancement of burst firing is caused by alterations in DA neuron physiology or is due to a circuit mechanism, we examined single cells in an ex vivo brain slice preparation. Substantia nigra DA neurons in brain slices fire in a rhythmic pattern but do not burst spontaneously because active glutamate inputs are no longer present. We measured neuronal firing using loose cell-attached recordings (Cui et al., 2007; Beckstead and Phillips, 2009) and simulated the effects of glutamate input through iontophoresis (40-200 ms pulses) of aspartic acid ( $800 \mathrm{~mm})$. Similar to our in vivo findings, we observed no effect of food restriction on baseline DA neuron firing rates (AL mice, $1.93 \pm 0.19 \mathrm{~Hz}, n=24$; FR mice, $1.87 \pm$ $\left.0.16 \mathrm{~Hz}, n=32 ; t_{(54)}=0.25, p=0.81\right)$. Although iontophoresis of aspartic acid typically produced several action potentials in DA neurons from AL mice (Fig. 2A), it consistently produced a stronger excitation in neurons from FR mice (Fig. 2B). Two-way RMANOVA analysis indicated that DA neurons from FR mice fire more action potentials in response to aspartic acid iontophoresis (Fig. $2 C ; n=25$ and 31 in AL and FR groups, respectively; main effect of diet, $F_{(1,54)}=7.485, p=0.0084$; main effect of pulse length, $F_{(4,216)}=73.52, p<0.0001$; diet-pulse interaction, $F_{(4,216)}=3.532, p=0.0081$; Sidak post hoc test). Further, the vast majority of cells that paused their firing in response to iontophoresis exhibited longer pauses before spontaneous rhythmic firing resumed (Fig. 2D; AL mice, $n=17-24$; FR mice, $n=19-29$; two-way ANOVA; main effect of diet, $F_{(1,233)}=28.05, p<$ 0.0001 ; diet-pulse interaction, $F_{(4,233)}=1.278, p=0.2792$; Sidak multiple-comparisons test). Spikes were counted immediately following aspartic acid iontophoresis until the beginning of the pause. In the rare cases that no pause was detectible, spikes were counted until the previous rate of spontaneous rhythmic firing resumed. Further analysis of single neurons from the $200 \mathrm{~ms}$ iontophoretic pulse data indicated that total spike count and pause length were correlated in both groups (Fig. 2E; AL mice, $R^{2}=0.52, p<0.0001 ;$ FR mice, $R^{2}=0.33, p=0.0011$ ), but the slopes of these curves were not different from each other $\left(F_{(1,49)}=0.69, p=0.41\right)$. These results suggest that increased glutamate receptor sensitivity could be responsible for the increased burst firing observed in FR mice.

A more detailed analysis of the aspartate-induced firing was conducted to determine whether burst firing was also enhanced by food restriction. As the RGS method of burst identification used in Figure 1 is impractical in an ex vivo preparation, we defined a burst using the original guidelines set forth by Grace and Bunney (1984) (i.e., a burst begins with an interspike interval of $<80 \mathrm{~ms}$ and terminates with an interval $>160 \mathrm{~ms}$ ). Two-way ANOVA indicated that the shortest interspike interval measured was lower in DA neurons from FR mice when compared with AL mice (Fig. 3A; AL mice, $n=16-25$; FR mice, $n=26-31$; main effect of diet, $F_{(1,255)}=54.54, p<0.0001$; diet-pulse interaction, $F_{(4,255)}=1.291, p=0.27$; Sidak multiple-comparisons test). Note that interspike intervals could not be calculated in cases where only one spike was observed, which occurred in nine AL mice cells and five FR mice cells in response to a $40 \mathrm{~ms}$ iontophoresis. Consistent with the shorter interspike intervals, aspartic acid produced a burst in a significantly higher percentage of cells from FR mice (Fig. $3 B$; AL mice, $n=25$; FR mice, $n=31 ; \chi^{2}$ analysis, $p=$ $0.0001)$. Not only were DA neurons from FR mice more prone to bursting, but they also exhibited a higher number of spikes within those bursts (Fig. 3C; AL mice, $n=6-15$ of 25 cells; FR mice, $n=$ $24-28$ of 31 cells that met burst criteria for each point; two-way ANOVA; main effect of diet, $F_{(1,133)}=6.685, p=0.0108$; dietpulse interaction, $\left.F_{(3,133)}=0.3693, p=0.775\right)$. These results suggest that not only are DA neurons from FR mice more sensitive to glutamate receptor activation, but this enhanced sensitivity could also produce increased burst firing.

We next tested whether DA neurons from FR mice exhibit enhanced firing in response to depolarization occurring independently of glutamate receptor activation. We conducted electrophysiological experiments in the current-clamp configuration and adjusted the current so that the cell was resting at $-60 \mathrm{mV}$ at the beginning of each experiment. We then stepped each cell using depolarizing current injections from 50 to $500 \mathrm{pA}$ in $50 \mathrm{pA}$ increments (Fig. 4A). When we compared the number of action potentials induced by near-threshold depolarizations, no significant difference was observed between DA neurons from AL mice compared with FR mice (Fig. $4 B$; AL mice, $n=18$; FR mice, $n=17$; two-way RMANOVA; main effect of diet, $F_{(1,33)}=1.33, p=0.2572$; main effect of current injection, $F_{(9,297)}=9.858$, $p<0.0001$; dietcurrent interaction, $\left.F_{(9,297)}=1.005, p=0.436\right)$. Larger current injections in neurons from FR mice did appear to produce a trend toward fewer spikes. Food restriction had no effect on either rheobase (the minimum amount of current injection required to elicit a spike; Fig. $4 C$; two-sample $t$ test, $t_{(33)}=0.03, p=0.98$ ) or the threshold voltage of the first spike fired (Fig. $4 D$; two-sample $t$ test, $t_{(33)}=$ $0.24, p=0.81$ ). This suggests that food restriction does not produce a general increase in DA neuron firing sensitivity, and is consistent with the notion that changes in neurotransmitter receptor signaling are responsible for the increased bursting in FR mice. 

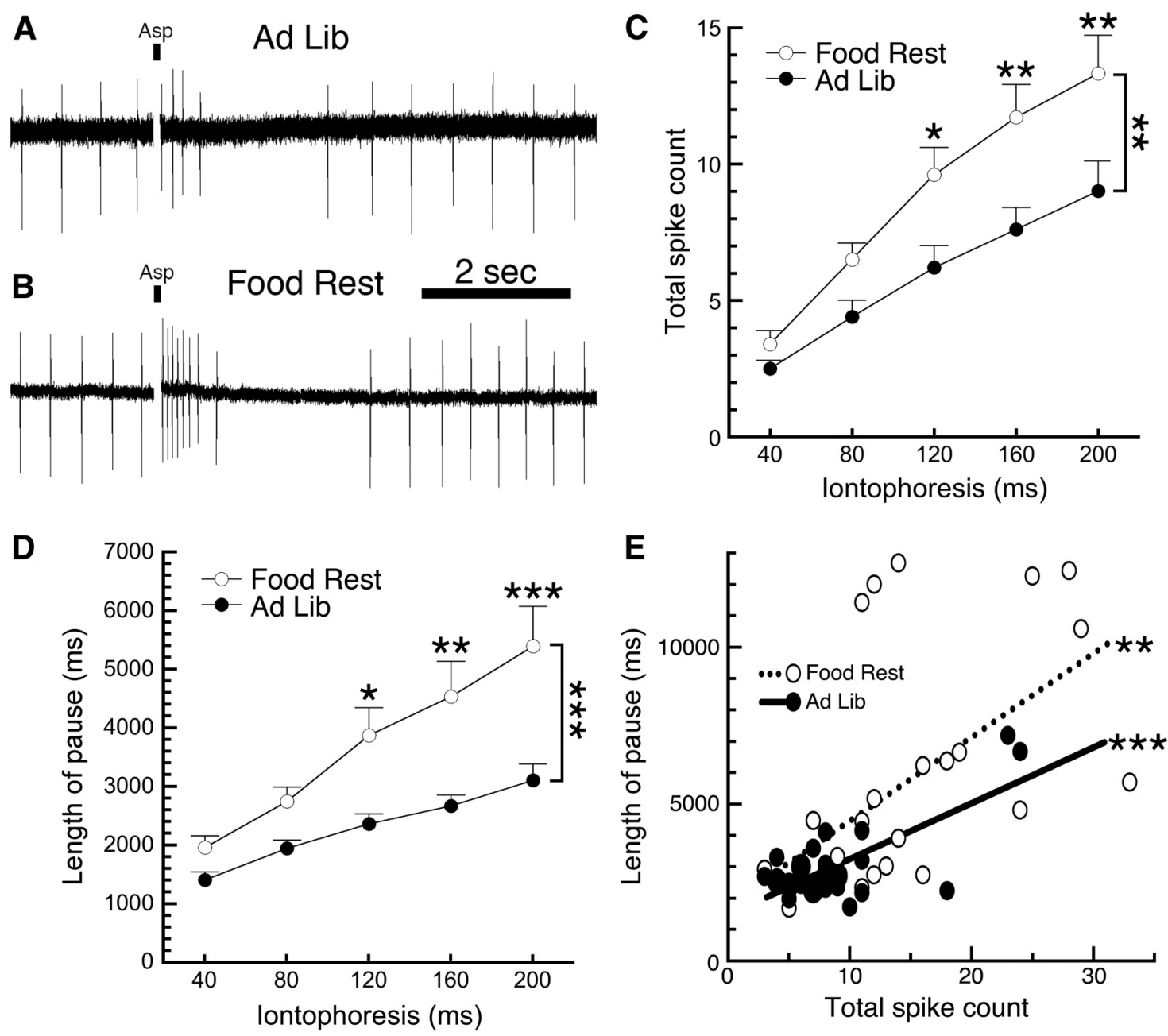

Figure 2. Food restriction increases the sensitivity of DA neurons to aspartic acid. Firing of substantia nigra DA neurons was monitored using loose cell-attached recordings. $A$, A sample trace shows that an $80 \mathrm{~ms}$ iontophoretic pulse of aspartic acid (indicated by a small black bar) in a neuron from an ad libitum-fed mouse produced a brief increase in firing rate followed by a pause. $\boldsymbol{B}$, When the same pulse was applied to a DA neuron from a food-restricted mouse, it produced more action potentials followed by a longer pause when compared with ad libitum controls. $\boldsymbol{C}, \boldsymbol{D}, \mathrm{DA}$ neurons from food-restricted mice exhibited a greater number of spikes $(\boldsymbol{C})$ and a longer pause length $(\boldsymbol{D})$ across a range $(40-200 \mathrm{~ms})$ of iontophoretic applications of aspartic acid. $\boldsymbol{E}$, Analysis of the physiological consequences of the $200 \mathrm{~ms}$ ejection indicated that total spike count and pause length were significantly correlated in cells from both AL and FR mice; however, the two slopes were not significantly different from each other. ${ }^{*} p<0.05,{ }^{* *} p<0.01,{ }^{* * *} p<0.001$. Food Rest, food restricted; Ad Lib, ad libitum.
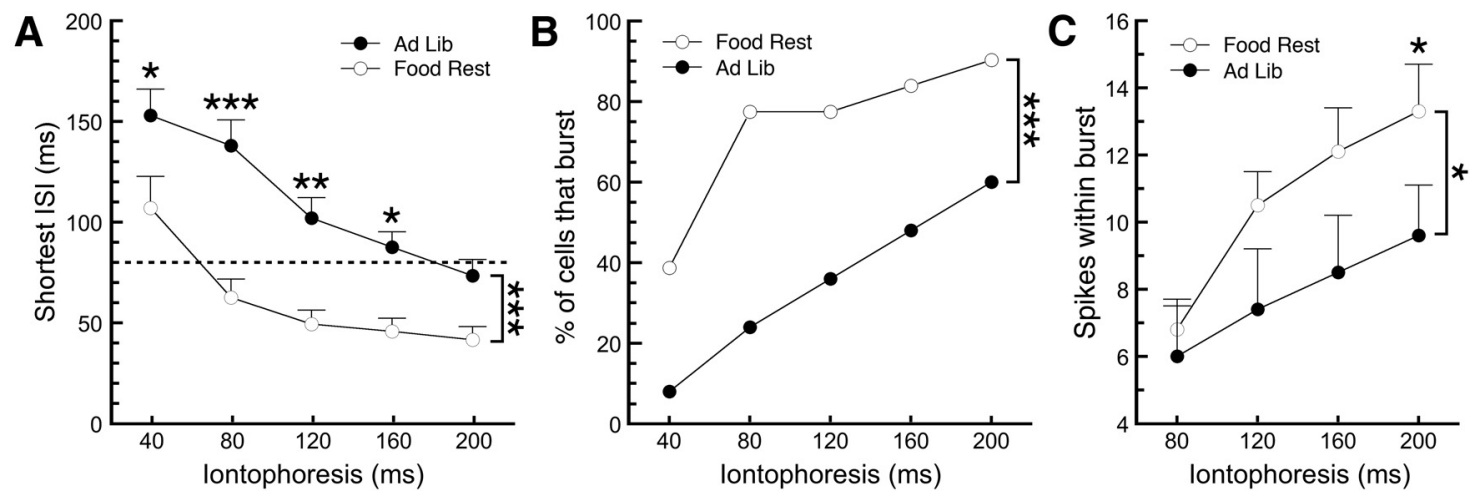

Figure 3. Food restriction increases burst firing of DA neurons in brain slices. $A, A$ further analysis of the iontophoresis data suggested that the shortest interspike interval (ISI) in response to aspartic acid iontophoresis was significantly lower in DA neurons from food-restricted mice than in those from ad libitum-fed mice. In our brain slice experiments, a cell was deemed to have fired a burst of action potentials if the interspike interval between any two spikes was $<80 \mathrm{~ms}$ (dashed line in $A$ ), and bursts were considered terminated with the first interspike interval afterward that was $>160 \mathrm{~ms}$. $\boldsymbol{B}$, Using these criteria, DA neurons from food-restricted mice were significantly more susceptible to firing a burst in response to iontophoresis of aspartic acid. C, DA neurons from food-restricted mice also exhibited an increased number of spikes within those bursts. ${ }^{*} p<0.05,{ }^{* *} p<0.01,{ }^{* * *} p<0.001$. Food Rest, Food restricted; Ad Lib, ad libitum. 

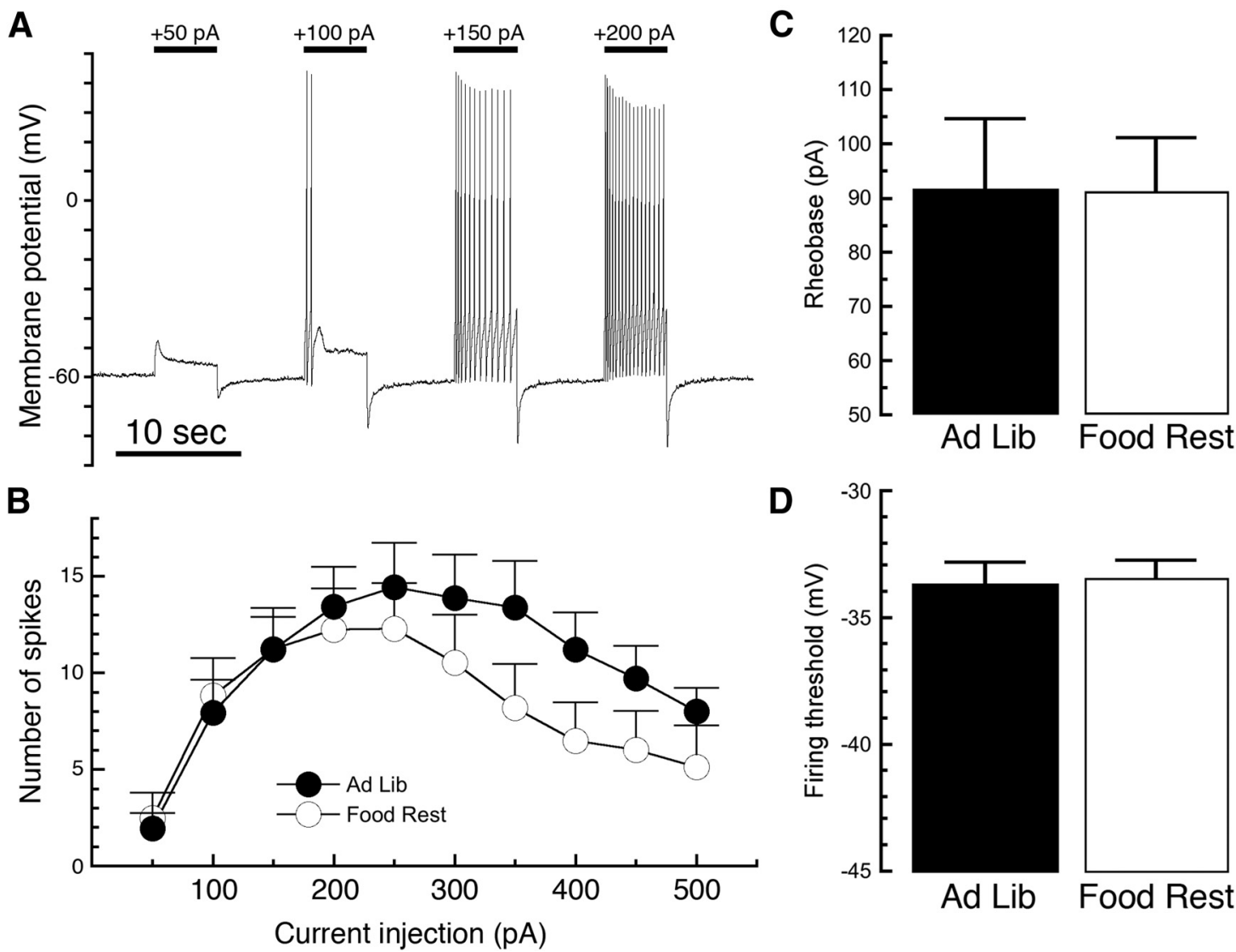

Figure 4. Food restriction does not affect depolarization-induced firing of DA neurons. DA neurons were recorded in the current-clamp configuration, and the initial current injection was adjusted so that the cell was resting at $-60 \mathrm{mV}$. A series of $5 \mathrm{~s}$ depolarizing current injections was then applied in $50 \mathrm{pA}$ increments, increasing from 50 to $500 \mathrm{pA}$ ( $\boldsymbol{A}$ ). The number of spikes produced by this procedure was not significantly different in cells from FR mice as opposed to AL controls $(\boldsymbol{B})$. There was, however, a trend toward greater susceptibility to depolarization block after large current injections in cells from food-restricted mice. There was no significant effect of food restriction on the minimum current required to elicit the first spike (rheobase, $\boldsymbol{C}$ ) or on the firing threshold of the first spike (D). Food Rest, Food restricted; Ad Lib, ad libitum.

To further investigate the increased glutamate receptor sensitivity, we next performed a voltage-clamp experiment with a cesium-based internal solution and held the neurons at $40 \mathrm{mV}$ to relieve the magnesium block of NMDA receptor channels. We then electrically stimulated neurotransmitter release and measured the AMPAR/NMDAR ratio, an established measure of glutamatergic synaptic strength (Ungless et al., 2001; Borgland et al., 2004). We observed a larger AMPAR/NMDAR ratio in DA neurons from FR mice when compared with those from AL mice (Fig. 5; two-sample $t$ test by cell; AL mice, $n=14$; FR mice, $n=$ $15 ; t_{(27)}=2.283, p=0.0305$; by mouse, $n=6$ mice in each group, $\left.t_{(10)}=2.725, p=0.0214\right)$. This suggests that an increase in glutamatergic synaptic strength contributes to the increased burst firing produced by chronic food restriction.

Our in vivo recordings (Fig. 1) suggested that cocaine increases burst firing of DA neurons only in FR mice. Cocaine is a biogenic amine uptake inhibitor, and one of its principal actions in the brain is inhibition of DA uptake leading to increased extracellular levels of the neurotransmitter. DA neuron stimulation releases DA somatodendritically (Geffen et al., 1976; Kalivas and Duffy, 1991), which can activate D2 autoreceptors and an associated G-protein-coupled potassium (GIRK) conductance that strongly inhibits cell firing (Lacey et al., 1987; Pucak and Grace, 1994; Beckstead et al., 2004). We thus hypothesized that D2 autoreceptors contribute to the effects of food restriction on DA neurons and repeated the aspartate iontophoresis experiment in the presence of the D2-type receptor antagonist sulpiride (200
nM). Two-way RMANOVA indicated that in the presence of sulpiride there was no main effect of food restriction on the number of spikes fired in response to aspartic acid (Fig. 6A; AL mice, $n=43$; FR mice, $\left.n=34 ; F_{(1,75)}=0.9069, p=0.34\right)$; however, there was a significant interaction between the number of spikes and the time of ejection $\left(F_{(4,300)}=3.040, p=0.0177\right.$; Sidak post hoc test). Surprisingly, sulpiride did not eliminate the food restriction-induced increase in pause length (Fig. $6 B$; AL mice, $n=36-43$; FR mice, $n=28-34$; two-way ANOVA; main effect of diet, $F_{(1,359)}=24.46, p<0.0001$; diet-pulse interaction, $F_{(4,359)}=2.593, p=0.0364$; Sidak post hoc test). An analysis of burst parameters indicated that in the presence of sulpiride there was a small but significant effect of food restriction on the shortest interspike interval (Fig. $6 C$; AL mice, $n=38-43$; FR mice, $n=$ 32-34; two-way ANOVA; $F_{(1,366)}=4.753, p=0.0299$; diet-pulse interaction, $\left.F_{(4,366)}=0.2183, p=0.9282\right)$; however, there was no statistically significant effect of food restriction at any individual pulse length. Sulpiride also effectively eliminated the effect of food restriction on the number of cells that fired traditional bursts in response to aspartic acid (Fig. $6 D$; AL mice, $n=43$; FR mice, $n=34 ; \chi^{2}$ analysis, $\left.p=0.37\right)$. Together, this suggests that differential inhibition by D2 autoreceptors may contribute to the effects of food restriction on dopamine neuron firing.

To further investigate how cocaine may affect D2 autoreceptor signaling in DA neurons of FR mice, we performed a voltageclamp experiment in which we used a potassium-based internal solution and held the neurons at $-55 \mathrm{mV}$. We obtained maximal 
A

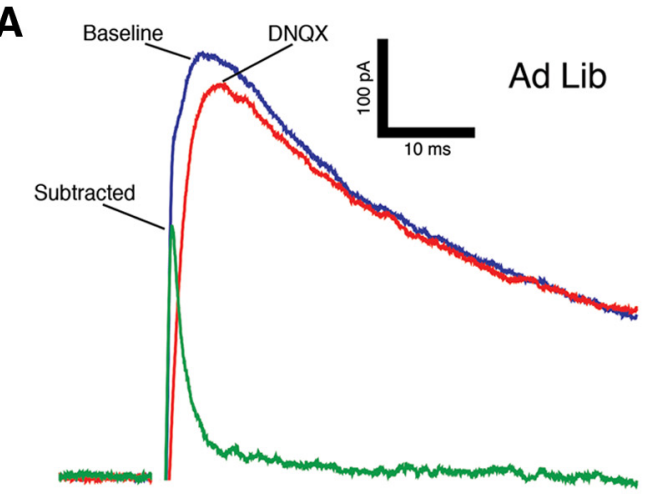

B

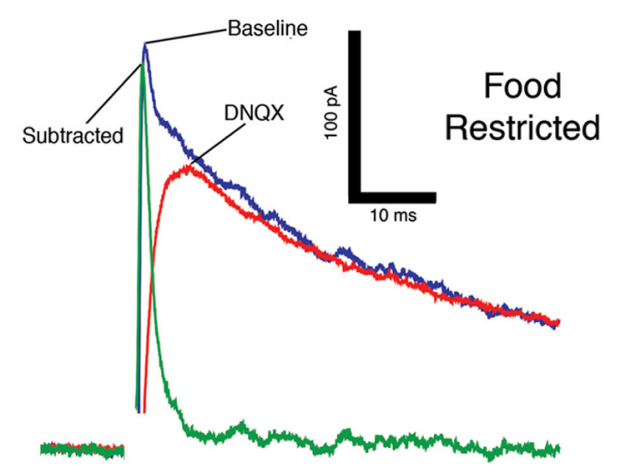

C

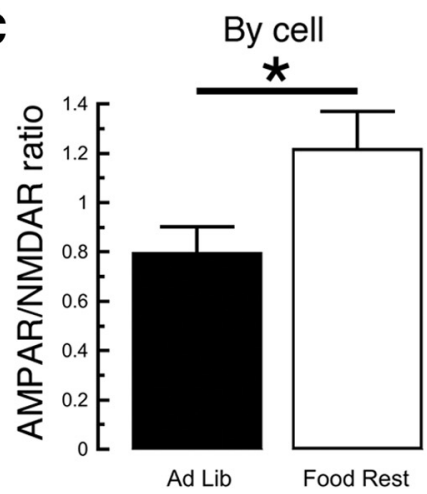

D

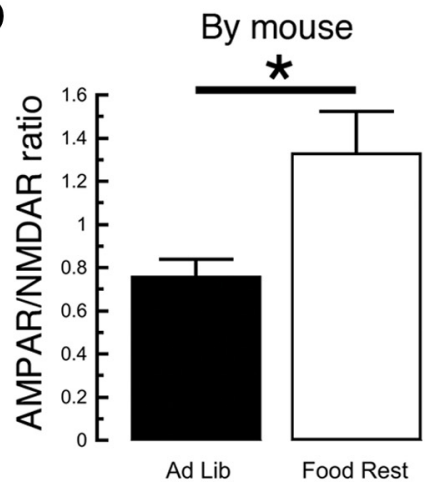

Figure 5. Food restriction enhances AMPAR/NMDAR ratios in DA neurons. $\boldsymbol{A}, \boldsymbol{B}$, Using a cesium-based pipette solution, we electrically evoked glutamate-mediated synaptic currents while holding the neuron at $40 \mathrm{mV}(\boldsymbol{A}, \boldsymbol{B}$, blue trace). We then applied the AMPA receptor antagonist DNQX $(10 \mu \mathrm{m})$, observed the remaining NMDA receptor-mediated current (red trace), and measured the difference between the two traces to determine the amplitude of the AMPA receptor contribution (green trace). DA neurons from food-restricted mice exhibited a proportionately greater contribution from AMPA receptors than ad libitum (Ad Lib) controls $(\boldsymbol{A}, \boldsymbol{B}) . \boldsymbol{C}, \boldsymbol{D}$, There was a significant difference in the AMPAR/NMDAR amplitude ratios regardless of whether each neuron was counted as its own data point $(\boldsymbol{C})$ or whether multiple cells from each mouse were averaged and analyzed as one data point $(\boldsymbol{D})$. ${ }^{*} p<0.05$.

D2 receptor-mediated currents through repeated iontophoresis of $1 \mathrm{M} \mathrm{DA}$, as we have published previously (Beckstead and Williams, 2007; Paladini et al., 2007; Beckstead and Phillips, 2009; Branch and Beckstead, 2012). Surprisingly, there was no significant effect of food restriction alone on the maximum amplitude of D2 autoreceptor-mediated currents (FR mice, $191 \pm 10.1 \mathrm{pA}$; AL mice, $205 \pm 13.1 \mathrm{pA} ; n=47$ and 28, respectively; two-sample $t$ test, $\left.t_{(73)}=0.83, p=0.41\right)$. We then applied cocaine $(10 \mu \mathrm{M})$ for $12 \mathrm{~min}$ by bath perfusion and measured the change in D2 receptor-mediated currents (Fig. $7 A, B$, top). We observed that D2 currents in DA neurons from FR mice showed enhanced desensitization when compared with AL mice and did not recover as cocaine began to wash out (Fig. 7C; AL mice, $n=9$; FR mice, $n=$ 19; two-way ANOVA; main effect of diet, $F_{(1,76)}=6.720, p=$ 0.0114 ; main effect of time, $F_{(2,76)}=1.843, p=0.1653$; diet-time interaction, $F_{(2,76)}=1.397, p=0.2536$; Sidak multiplecomparisons test, $p<0.01$ for the last time point), although this effect developed somewhat more slowly than the effects of cocaine that we observed in vivo.

To determine whether the difference between groups was due directly to prolonged activation of $\mathrm{D} 2$ receptors, we repeated the same experiment except that we used a $50 \mathrm{~s}$ iontophoresis of $1 \mathrm{M}$ DA instead of cocaine to induce desensitization (Fig. $7 A, B$, bottom). We again observed that D2 currents in neurons from FR mice did not recover after desensitization (Fig. 7D; AL mice, $n=$ 6; FR mice, $n=8$; two-way ANOVA; main effect of diet, $F_{(1,39)}=$ $17.43, p=0.0002$; main effect of time, $F_{(2,39)}=2.559, p=0.0903$;

diet-time interaction, $F_{(2,39)}=1.678, p=$ 0.1999; Sidak multiple-comparisons test, $p<0.01$ for last time point). This suggests that food restriction increases the sensitivity of D2 autoreceptors to activationdependent desensitization and is consistent with the enhanced cocaine effects observed in these mice.

Finally, we sought to investigate the persistence of the food restriction-induced changes in burst firing. We added two new dietary conditions: a re-fed group that was chronically food restricted and subsequently returned to ad libitum conditions for $10 \mathrm{~d}$; and an acutely fasted group that was only deprived of food overnight. Body weights for the restricted/re-fed group initially, during food restriction, and after refeeding were $23.3 \pm 0.7,19.6 \pm 0.8$, and $27.0 \pm 0.6 \mathrm{~g}$, respectively $(n=6)$. The body weights for the acutely fasted group were $28.0 \pm 1.0 \mathrm{~g}$ before fasting and $24.6 \pm 0.9 \mathrm{~g}$ following the overnight fast. We subsequently investigated the burst firing of DA neurons in slices from these mice. Two-way RMANOVA analysis indicated that upon iontophoresis of aspartic acid, dopamine neurons from re-fed mice fired a larger number of action potentials than the acutely food-restricted mice (Fig. 8A; re-fed mice, $n=36$; acutely fasted mice, $n=24$; main effect of diet, $F_{(1,58)}=7.783, p=0.0071$; diet-pulse interaction, $F_{(4,232)}=2.718, p=$ 0.0305 ; Sidak post hoc test). There was a significant main effect of diet on pause length (Fig. $8 B$; re-fed mice, $n=34-36$; acutely fasted mice, $n=23-24$; two-way ANOVA; $F_{(1,284)}=7.914, p=$ $0.0052)$, but there was not a significant diet-pulse length interaction $\left(F_{(4,284)}=1.047, p=0.3833\right.$; Sidak multiple-comparisons test $)$. There was also a significant main effect of diet on the shortest interspike interval (Fig. $8 C$; re-fed mice, $n=36$; acutely fasted mice, $n=30$; two-way ANOVA; $F_{(1,308)}=25.94, p<0.0001$; diet-pulse interaction, $F_{(4,308)}=0.2857, p=0.887$ ), and neurons from re-fed mice were more likely to fire bursts than cells from acutely fasted mice (Fig. $8 D$; re-fed mice, $n=36$; acutely fasted mice, $n=30 ; \chi^{2}$ analysis, $p=0.0181$ ). Our results indicate that food restrictioninduced adaptations in firing do not occur immediately (i.e., overnight) upon food deprivation but, once induced, will persist for at least $10 \mathrm{~d}$ after returning the mice to free feeding.

\section{Discussion}

Our findings suggest that food restriction increases the excitability of substantia nigra DA neurons through multiple neuroadaptive mechanisms. Food restriction increases the propensity of DA neurons to fire bursts of action potentials, an effect that is enhanced by the psychomotor stimulant cocaine. The increased burst firing is due to increased glutamate receptor sensitivity and is not due to a generalized increase in sensitivity to depolarization. D2 autoreceptors also contribute to increased burst firing, as the excitatory effects of food restriction on DA neuron firing are reduced by sulpiride and receptor desensitization is enhanced by food restriction. This mechanism could link food restriction to the cocaine-induced increase in burst firing observed in vivo. 
Finally, increased burst firing is not induced by an overnight fast, but, once induced, it will persist for at least $10 \mathrm{~d}$ following a return to free feeding. These results identify the substantia nigra as a convergence point for the interactions between feeding state and drug abuse. Increased postsynaptic glutamate receptor transmission combined with decreased D2 autoreceptor signaling could work in synergy to contribute to the behavioral interactions between food restriction and drug use.

Feeding state and drug reinforcement Food intake and drug abuse exhibit a complex behavioral relationship. In rodents, food restriction increases selfadministration of most major classes of abused drugs (Carroll et al., 1979; de la Garza et al., 1981; Carroll and Meisch, 1984, Carroll, 1985; de la Garza and Johanson, 1987; Macenski and Meisch, 1999; Shalev et al., 2000, 2003; Carr, 2002). Thus, determining the cellular mechanisms responsible for the interactions between feeding state and drug use could have important implications for the treatment of drug abuse.

DA neurons in both the substantia nigra and the ventral tegmental area (VTA) are logical candidates to play a primary role in these interactions because they have been implicated in both natural and chemical-mediated reinforcement (Wise, 2004). Populations of neurons in both areas code an error prediction signal in response to an unexpected reward or an associated conditioned stimulus (Schultz, 2002). Both feeding and drugs of abuse increase extracellular DA levels in forebrain terminal regions (Di Chiara and Imperato, 1988; Westerink et al., 1994), suggesting that overlapping central mechanisms are responsible for their reinforcing properties (Davis et al., 2008). Studies using genetically engineered dopamine-deficient mice indicate that the dorsal striatum is a key mediator of normal feeding behavior (Szczypka et al., 2001; Sotak et al., 2005; Hnasko et al., 2006). Thus, in this study we focused on the substantia nigra because it is the main source of DA projections to the dorsal striatum. The VTA is also implicated in motivated behavior, and we would predict that feeding-induced cellular adaptations occur there as well. Seeking of both food and cocaine is accompanied by the subsecond release of DA in the nucleus accumbens, presumably the result of phasic firing of VTA DA neurons (Phillips et al., 2003; Roitman et al., 2004).

Our present results suggest that food restriction increases the sensitivity of DA neurons to glutamate receptor-induced burst firing. This adaptation could increase the strength of natural reinforcers during times of need and minimize it during times of plenty. Enhanced burst firing may not simply augment food reinforcement but may also increase the behavioral effects of other reinforcers, including drugs of abuse. Food restriction augments the increase in accumbal DA produced by cocaine (Rougé-Pont et al., 1995) while either decreasing or not affecting tonic DA levels (Pothos et al., 1995; Stuber et al., 2002; Cadoni et al., 2003).
Increasing the propensity of DA neurons to burst could thus augment reinforcer strength by enhancing the difference between tonic and phasic levels of extracellular DA (i.e., increasing the relative amplitude of this important learning signal). Interestingly, the adaptations responsible for increased bursting do not develop overnight but, once induced, will persist for at least $10 \mathrm{~d}$ following re-feeding and recovery of body weight. We did not observe elevated basal firing rates in our FR mice, in contrast to data from the rat VTA published in a review article by Marinelli et al. (2006). This conflicting result could be due to species-specific or brain region-specific differences in sensitivity to feeding state, or perhaps to subtle differences in the restriction protocol or the recording procedure.

\section{Glutamate receptor-induced burst firing}

In vivo, DA neurons can switch between irregular single-pulse firing and a more active bursting mode (Grace and Bunney, 1984). We observed a food restriction-induced increase in burst frequency, possibly indicating that glutamate inputs that did not previously code for a rewarding stimulus had become capable of doing so. We then used aspartate iontophoresis to evoke bursting ex vivo and observed that neurons from FR mice exhibit increased sensitivity to burst firing. We also observed an FR-induced increase in AMPAR/NMDAR ratios, indicating increased glutamatergic synaptic strength. Noncontingent administration of cocaine increases AMPAR/NMDAR ratios in VTA DA neurons (Ungless et al., 2001), an effect that persists for $\sim 1$ week and may contribute to behavioral sensitization (Borgland et al., 2004). While cocaine-induced increases in AMPAR/NMDAR ratios are 
A

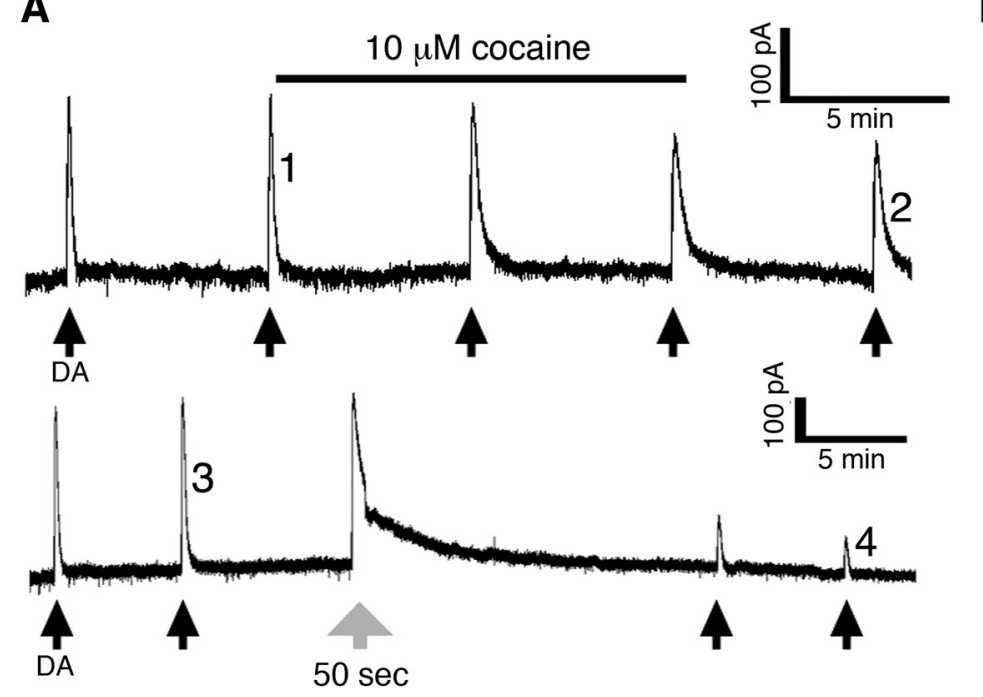

B

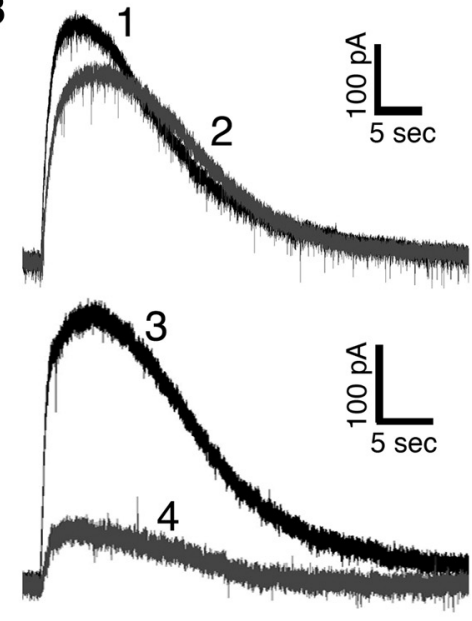

C
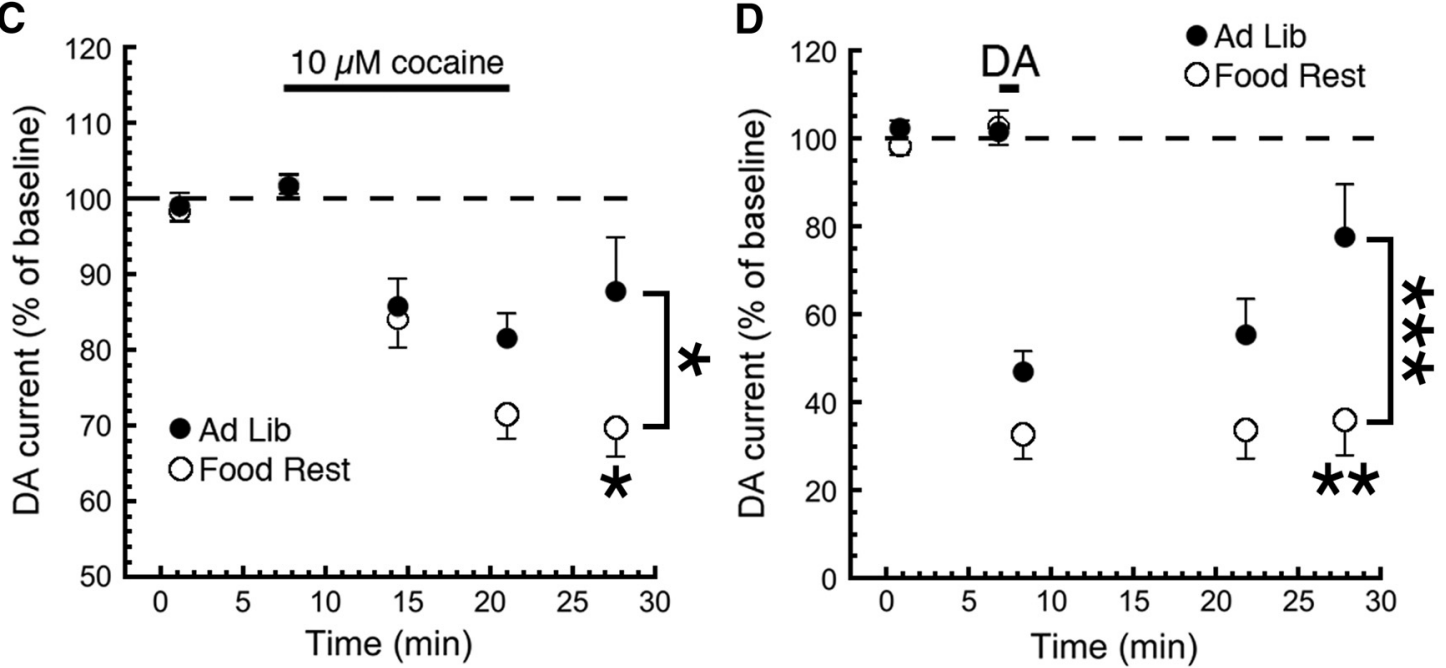

Figure 7. Food restriction enhances desensitization of D2 autoreceptors. Using a potassium-based pipette solution, we measured the GIRK channel D2 autoreceptor-mediated outward current that occurs in response to a maximal iontophoresis of DA $(1 \mathrm{M})$. $A$, lontophoresis was repeated every $6 \mathrm{~min}$ (black arrows) until a stable baseline was obtained, at which time the DAT inhibitor cocaine $(10 \mu \mathrm{M})$ was applied by bath perfusion. Numbered events from $\boldsymbol{A}$ are enlarged in $\boldsymbol{B}$ to better show outward currents that were observed before and after the application of cocaine ( $\boldsymbol{B}$, top) or dopamine ( $\boldsymbol{B}$, bottom). $\boldsymbol{B}, \boldsymbol{C}$, During washout from a $12 \mathrm{~min}$ application of cocaine, we observed that the currents ( $\boldsymbol{B}$, example trace 1 vs example trace 2 ) recovered significantly more slowly in neurons from food-restricted mice ( $\boldsymbol{C}$. To determine whether this difference is due directly to the activation of $\mathrm{D} 2$ autoreceptors, we conducted a separate experiment where desensitization was induced by a long $(50 \mathrm{~s}$ ) iontophoretic pulse of dopamine (large gray arrow in $\boldsymbol{A}$ ). We observed a diminished recovery from desensitization ( $\boldsymbol{B}$, example trace $3 \mathrm{vs}$ example trace 4 ) in neurons from food-restricted mice (D). The data point in $\boldsymbol{D}$ immediately following the iontophoretic pulse indicates the remaining outward current at the end of that pulse. ${ }^{*} p<0.05$, ${ }^{* *} p<0.01$, ${ }^{* * *} p<0.001$. Food Rest, Food restricted; Ad Lib, ad libitum.

sustained for a longer duration than those induced by reward learning for food, both reinforcers are capable of increasing synaptic strength (Chen et al., 2008). Increased AMPAR/NMDAR ratios are associated with increased terminal DA release (Stuber et al., 2008); thus, they are logical mediators of enhanced behavioral reinforcement. Glutamatergic synaptic potentials are brief, and, consistent with our findings, their enhancement could increase stimulated burst firing while not elevating basal firing rates.

\section{D2 autoreceptor signaling}

Midbrain DA neurons release DA from their cell bodies and dendrites (Björklund and Lindvall, 1975; Kalivas and Duffy, 1991). This DA can bind to somatodendritic D2 autoreceptors, powerfully inhibiting firing by activating a GIRK channel-mediated conductance (Lacey et al., 1987; Pucak and Grace, 1994; Beckstead et al., 2004). Growing evidence suggests that D2 autoreceptor signaling is a determinant of cocaine-related behaviors. Rats that exhibit a high response to novelty are less sensitive to a D2 receptor agonist (Marinelli and White, 2000), and their VTA DA neurons are more sensitive to the increased firing observed during withdrawal from cocaine self-administration (McCutcheon et al., 2009). Subsensitivity of somatodendritic D2 receptors occurs in response to repeated cocaine exposure (Henry et al., 1989) and for several days following withdrawal from cocaine selfadministration (Marinelli et al., 2003). D2 receptor signaling limits high-dose cocaine self-administration and may curtail drug intake toward the end of a binge (Caine et al., 2002; De Mei et al., 2009). Additionally, a recent study found that mice lacking D2 autoreceptors on DA neurons are supersensitive to the rewarding properties of low doses of cocaine (Bello et al., 2011). Thus, any manipulation that decreases D2 autoreceptor signaling could profoundly enhance behavior associated with cocaine exposure.

Cocaine increases extracellular concentrations of DA by inhibiting the uptake transporter DAT. Thus, the decrease in spon- 
A
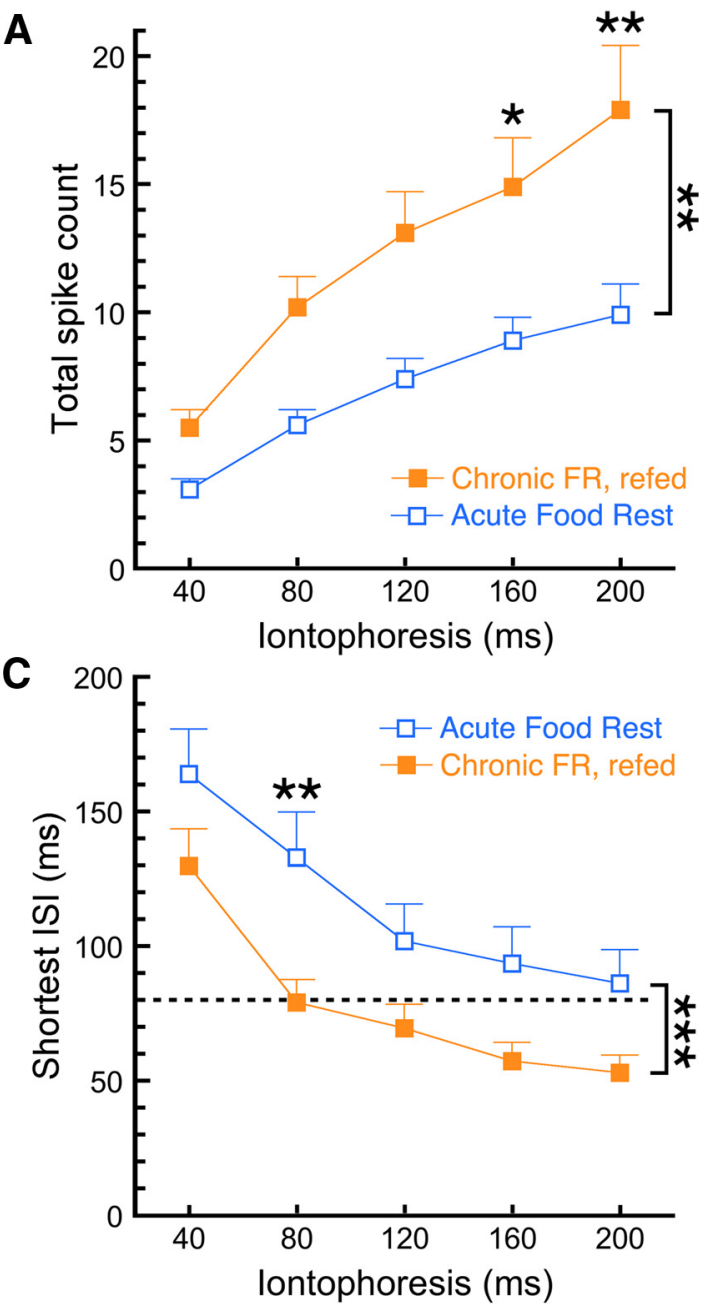

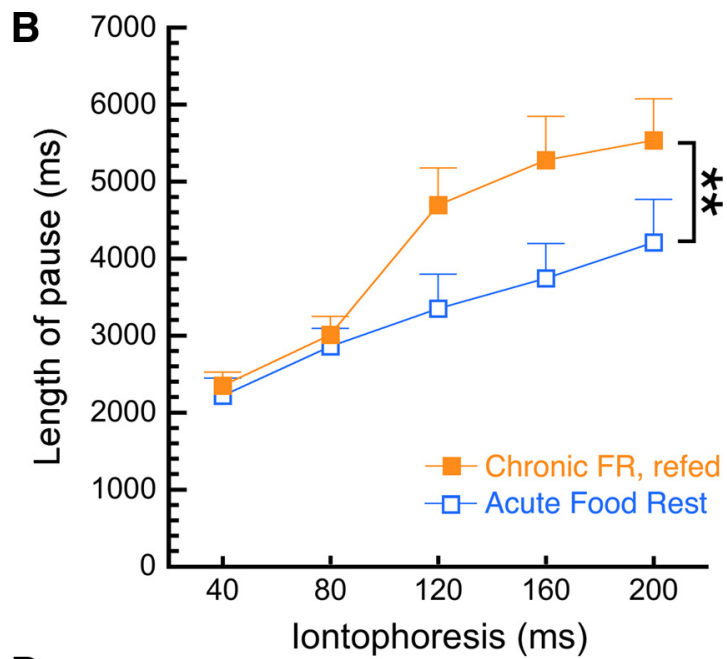

D

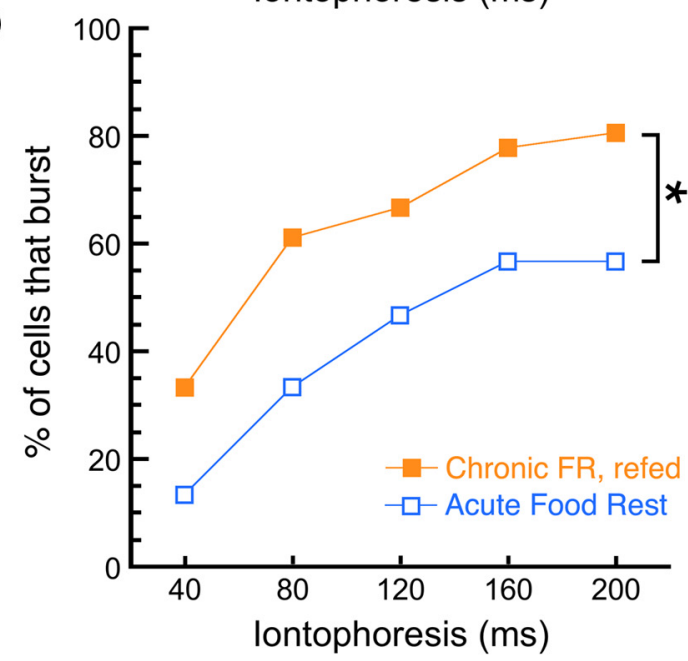

Figure 8. Food restriction-induced adaptations in burst firing are time sensitive and persist after re-feeding. Dopamine neurons in brain slices from two additional groups of mice were examined to investigate the time course of the effects of food restriction on burst firing. Mice were either acutely food deprived (overnight) and killed the next day or chronically food restricted and returned to ad libitum feeding for $10 \mathrm{~d}$ before being killed. $\boldsymbol{A}$, Upon iontophoretic application of aspartic acid, re-fed mice exhibited a higher total spike count compared with the acutely fasted group. $\boldsymbol{B}$, DA neurons from re-fed mice also exhibited longer pause lengths than neurons from acutely fasted mice. $C, D$, An analysis of burst parameters indicated that the re-fed group exhibited shorter minimum interspike intervals than the acute group $(\boldsymbol{C})$ and a larger percentage of cells that fired bursts in response to iontophoresis $(\boldsymbol{D}) .^{*} p<0.05,{ }^{* *} p<0.01,{ }^{* * *} p<0.001$. Food Rest, Food restricted.

taneous firing rate that we observed in vivo subsequent to cocaine injection was likely due to the activation of D2 autoreceptors. In our brain slice recordings, we observed a food restriction-induced decrease in D2 autoreceptor signaling subsequent to prolonged activation with cocaine or iontophoresis of DA. This is consistent with the established propensity of D2 autoreceptor-mediated neurotransmission to undergo a desensitization-dependent long-term depression (Beckstead and Williams, 2007). Furthermore, pharmacologically blocking D2 receptors decreased the food restrictioninduced enhancement of firing produced by aspartic acid. D2 autoreceptor-mediated potentials persist for $\sim 1$ s (Beckstead et al., 2004); thus, our findings are consistent with a role for D2 receptors in limiting the number of spikes in a burst. Since D2 autoreceptors inhibit firing, the food restriction-induced inhibition of autoreceptor signaling would enhance firing and could contribute to the increased bursting observed in those mice. This could increase the phasic release of dopamine in terminal regions and contribute to the myriad increases in drug reinforcement previously reported as consequences of food restriction.

We have previously shown that activation of D2 autoreceptormediated synaptic transmission can produce a pause in DA neuron firing (Beckstead et al., 2004); thus, it was surprising that the food restriction-induced enhancement of the aspartate-induced pause was unaffected by sulpiride. The increase in pause length could be due either to an increase in metabotropic glutamate receptor sensitivity or to a general increase in susceptibility to depolarization block. The trend of cells from FR mice to fire fewer action potentials upon injection of high levels of depolarizing current (Fig. 4B) along with the positive correlation between spike number and pause length could suggest that food restriction increases sensitivity to depolarization block.

In summary, our findings identify substantia nigra DA neurons as a plausible locus for many of the mechanistic interactions between feeding state and drug abuse. We propose a dual mechanism to explain some of the behavioral consequences of food restriction. Increased glutamatergic signaling could enhance burst firing and increase the strength of reinforcing stimuli, while decreased D2 autoreceptor signaling could augment this effect by removing a powerful form of inhibition during strong glutamatergic input or in the presence of cocaine. Future work is necessary to determine the specific contributions of these neurophysiological adaptations to the behavioral interaction between feeding state and drug abuse. 


\section{References}

Beckstead MJ, Phillips TJ (2009) Mice selectively bred for high or low alcohol-induced locomotion exhibit differences in dopamine neuron function. J Pharmacol Exp Ther 329:342-349. CrossRef Medline

Beckstead MJ, Williams JT (2007) Long-term depression of a dopamine IPSC. J Neurosci 27:2074-2080. CrossRef Medline

Beckstead MJ, Grandy DK, Wickman K, Williams JT (2004) Vesicular dopamine release elicits an inhibitory postsynaptic current in midbrain dopamine neurons. Neuron 42:939-946. CrossRef Medline

Beckstead MJ, Gantz SC, Ford CP, Stenzel-Poore MP, Phillips PE, Mark GP, Williams JT (2009) CRF enhancement of GIRK channelmediated transmission in dopamine neurons. Neuropsychopharmacology 34:1926-1935. CrossRef Medline

Bello EP, Mateo Y, Gelman DM, Noaín D, Shin JH, Low MJ, Alvarez VA, Lovinger DM, Rubinstein M (2011) Cocaine supersensitivity and enhanced motivation for reward in mice lacking dopamine D2 autoreceptors. Nat Neurosci 14:1033-1038. CrossRef Medline

Björklund A, Lindvall O (1975) Dopamine in dendrites of substantia nigra neurons: suggestions for a role in dendritic terminals. Brain Res 83:531-537. CrossRef Medline

Blythe SN, Wokosin D, Atherton JF, Bevan MD (2009) Cellular mechanisms underlying burst firing in substantia nigra dopamine neurons. J Neurosci 29:15531-15541. CrossRef Medline

Borgland SL, Malenka RC, Bonci A (2004) Acute and chronic cocaineinduced potentiation of synaptic strength in the ventral tegmental area: electrophysiological and behavioral correlates in individual rats. J Neurosci 24:7482-7490. CrossRef Medline

Branch SY, Beckstead MJ (2012) Methamphetamine produces bidirectional, concentration-dependent effects on dopamine neuron excitability and dopamine-mediated synaptic currents. J Neurophysiol 108:802-809. CrossRef Medline

Brown HD, McCutcheon JE, Cone JJ, Ragozzino ME, Roitman MF (2011) Primary food reward and reward-predictive stimuli evoke different patterns of phasic dopamine signaling throughout the striatum. Eur J Neurosci 34:1997-2006. CrossRef Medline

Cadoni C, Solinas M, Valentini V, Di Chiara G (2003) Selective psychostimulant sensitization by food restriction: differential changes in accumbens shell and core dopamine. Eur J Neurosci 18:2326-2334. CrossRef Medline

Caine SB, Negus SS, Mello NK, Patel S, Bristow L, Kulagowski J, Vallone D, Saiardi A, Borrelli E (2002) Role of dopamine D2-like receptors in cocaine self-administration: studies with D2 receptor mutant mice and novel D2 receptor antagonists. J Neurosci 22:2977-2988. Medline

Carr KD (2002) Augmentation of drug reward by chronic food restriction: behavioral evidence and underlying mechanisms. Physiol Behav 76:353364. CrossRef Medline

Carr KD, Kim GY, Cabeza de Vaca S (2001) Rewarding and locomotoractivating effects of direct dopamine receptor agonists are augmented by chronic food restriction in rats. Psychopharmacology (Berl) 154:420428. CrossRef Medline

Carr KD, Tsimberg Y, Berman Y, Yamamoto N (2003) Evidence of increased dopamine receptor signaling in food-restricted rats. Neuroscience 119:1157-1167. CrossRef Medline

Carroll ME (1985) The role of food deprivation in the maintenance and reinstatement of cocaine-seeking behavior in rats. Drug Alcohol Depend 16:95-109. CrossRef Medline

Carroll ME, Meisch RA (1984) Increased drug-reinforced behavior due to food deprivation. Adv Behav Pharmacol 4:47-88.

Carroll ME, France CP, Meisch RA (1979) Food deprivation increases oral and intravenous drug intake in rats. Science 205:319-321. CrossRef Medline

Chen BT, Bowers MS, Martin M, Hopf FW, Guillory AM, Carelli RM, Chou JK, Bonci A (2008) Cocaine but not natural reward self-administration nor passive cocaine infusion produces persistent LTP in the VTA. Neuron 59:288-297. CrossRef Medline

Chergui K, Suaud-Chagny MF, Gonon F (1994) Nonlinear relationship between impulse flow, dopamine release and dopamine elimination in the rat brain in vivo. Neuroscience 62:641-645. CrossRef Medline

Cooper DC (2002) The significance of action potential bursting in the brain reward circuit. Neurochem Int 41:333-340. CrossRef Medline

Cui G, Bernier BE, Harnett MT, Morikawa H (2007) Differential regulation of action potential- and metabotropic glutamate receptor-induced $\mathrm{Ca}^{2+}$ signals by inositol 1,4,5-trisphosphate in dopaminergic neurons. J Neurosci 27:4776-4785. CrossRef Medline

Davis JF, Tracy AL, Schurdak JD, Tschöp MH, Lipton JW, Clegg DJ, Benoit SC (2008) Exposure to elevated levels of dietary fat attenuates psychostimulant reward and mesolimbic dopamine turnover in the rat. Behav Neurosci 122:1257-1263. CrossRef Medline

de la Garza R, Johanson CE (1987) The effects of food deprivation on the self administration of phsychoactive drugs. Drug Alcohol Depend 19:17-27. CrossRef Medline

de la Garza R, Bergman J, Hartel CR (1981) Food deprivation and cocaine self administration. Pharmacol Biochem Behav 15:141-144. CrossRef Medline

De Mei C, Ramos M, Iitaka C, Borrelli E (2009) Getting specialized: presynaptic and postsynaptic dopamine D2 receptors. Curr Opin Pharmacol 9:53-58. CrossRef Medline

Di Chiara G, Imperato A (1988) Drugs abused by humans preferentially increase synaptic dopamine concentrations in the mesolimbic system of freely moving rats. Proc Natl Acad Sci U S A 85:5274-5278. CrossRef Medline

Ford CP, Mark GP, Williams JT (2006) Properties and opioid inhibition of mesolimbic dopamine neurons vary according to target location. J Neurosci 26:2788-2797. CrossRef Medline

Geffen LB, Jessell TM, Cuello AC, Iversen LL (1976) Release of dopamine from dendrites in rat substantia nigra. Nature 260:258-260. CrossRef Medline

Gonon FG (1988) Nonlinear relationship between impulse flow and dopamine released by rat midbrain dopaminergic neurons as studied by in vivo electrochemistry. Neuroscience 24:19-28. CrossRef Medline

Grace AA, Bunney BS (1984) The control of firing pattern in nigral dopamine neurons: burst firing. J Neurosci 4:2877-2890. Medline

Heien ML, Wightman RM (2006) Phasic dopamine signaling during behavior, reward, and disease states. CNS Neurol Disord Drug Targets 5:99_ 108. CrossRef Medline

Henry DJ, Greene MA, White FJ (1989) Electrophysiological effect of cocaine in the mesoaccumbens dopamine system: repeated administration. J Pharmacol Exp Ther 251:833-839. Medline

Hnasko TS, Perez FA, Scouras AD, Stoll EA, Gale SD, Luquet S, Phillips PE, Kremer EJ, Palmiter RD (2006) Cre recombinase-mediated restoration of nigrostriatal dopamine in dopamine-deficient mice reverses hypophagia and bradykinesia. Proc Natl Acad Sci U S A 103:8858-8863. CrossRef Medline

Kalivas PW, Duffy P (1991) A comparison of axonal and somatodendritic dopamine release using in vivo dialysis. J Neurochem 56:961-967. CrossRef Medline

Ko D, Wilson CJ, Lobb CJ, Paladini CA (2012) Detection of bursts and pauses in spike trains. J Neurosci Methods 211:145-158. CrossRef Medline

Lacey MG, Mercuri NB, North RA (1987) Dopamine acts on D2 receptors to increase potassium conductance in neurones of the rat substantia nigra zona compacta. J Physiol 392:397-416. Medline

Lindblom J, Johansson A, Holmgren A, Grandin E, Nedergård C, Fredriksson R, Schiöth HB (2006) Increased mRNA levels of tyrosine hydroxylase and dopamine transporter in the VTA of male rats after chronic food restriction. Eur J Neurosci 23:180-186. CrossRef Medline

Lobb CJ, Troyer TW, Wilson CJ, Paladini CA (2011) Disinhibition bursting of dopaminergic neurons. Front Syst Neurosci 5:25. CrossRef Medline

Macenski MJ, Meisch RA (1999) Cocaine self-administration under conditions of restricted and unrestricted food access. Exp Clin Psychopharmacol 7:324-337. CrossRef Medline

Marinelli M, White FJ (2000) Enhanced vulnerability to cocaine selfadministration is associated with elevated impulse activity of midbrain dopamine neurons. J Neurosci 20:8876-8885. Medline

Marinelli M, Cooper DC, Baker LK, White FJ (2003) Impulse activity of midbrain dopamine neurons modulate drug-seeking behavior. Psychopharmacology (Berl) 168:84-98. CrossRef Medline

Marinelli M, Rudick CN, Hu XT, White FJ (2006) Excitability of dopamine neurons: modulation and physiological consequences. CNS Neurol Disord Drug Targets 5:79-97. CrossRef Medline

Mathon DS, Kamal A, Smidt MP, Ramakers GM (2003) Modulation of cellular activity and synaptic transmission in the ventral tegmental area. Eur J Pharmacol 480:97-115. CrossRef Medline

McCutcheon JE, White FJ, Marinelli M (2009) Individual differences in do- 
pamine cell neuroadaptations following cocaine self-administration. Biol Psychiatry 66:801-803. CrossRef Medline

Overton PG, Clark D (1997) Burst firing in midbrain dopaminergic neurons. Brain Res Rev 25:312-334. CrossRef Medline

Paladini CA, Beckstead MJ, Weinshenker D (2007) Electrophysiological properties of catecholaminergic neurons in the norepinephrine-deficient mouse. Neuroscience 144:1067-1074. CrossRef Medline

Phillips PE, Stuber GD, Heien ML, Wightman RM, Carelli RM (2003) Subsecond dopamine release promotes cocaine seeking. Nature 422: 614-618. CrossRef Medline

Pothos EN, Creese I, Hoebel BG (1995) Restricted eating with weight loss selectively decreases extracellular dopamine in the nucleus accumbens and alters dopamine response to amphetamine, morphine, and food intake. J Neurosci 15:6640-6650. Medline

Pucak ML, Grace AA (1994) Evidence that systemically administered dopamine antagonists activate dopamine neuron firing primarily by blockade of somatodendritic autoreceptors. J Pharmacol Exp Ther 271:1181-1192. Medline

Roitman MF, Stuber GD, Phillips PE, Wightman RM, Carelli RM (2004) Dopamine operates as a subsecond modulator of food seeking. J Neurosci 24:1265-1271. CrossRef Medline

Rougé-Pont F, Marinelli M, Le Moal M, Simon H, Piazza PV (1995) Stressinduced sensitization and glucocorticoids. II. Sensitization of the increase in extracellular dopamine induced by cocaine depends on stress-induced corticosterone secretion. J Neurosci 15:7189-7195. Medline

Schultz W (2002) Getting formal with dopamine and reward. Neuron 36: 241-263. CrossRef Medline

Schultz W (2006) Behavioral theories and the neurophysiology of reward. Annu Rev Psychol 57:87-115. CrossRef Medline

Sevak RJ, Koek W, Owens WA, Galli A, Daws LC, France CP (2008) Feeding conditions differentially affect the neurochemical and behavioral effects of dopaminergic drugs in male rats. Eur J Pharmacol 592:109-115. CrossRef Medline

Shalev U, Highfield D, Yap J, Shaham Y (2000) Stress and relapse to drug seeking in rats: studies on the generality of the effect. Psychopharmacology (Berl) 150:337-346. CrossRef Medline

Shalev U, Marinelli M, Baumann MH, Piazza PV, Shaham Y (2003) The role of corticosterone in food deprivation-induced reinstatement of cocaine seeking in the rat. Psychopharmacology (Berl) 168:170-176. CrossRef Medline

Sotak BN, Hnasko TS, Robinson S, Kremer EJ, Palmiter RD (2005) Dysregulation of dopamine signaling in the dorsal striatum inhibits feeding. Brain Res 1061:88-96. CrossRef Medline

Stuber GD, Evans SB, Higgins MS, Pu Y, Figlewicz DP (2002) Food restriction modulates amphetamine-conditioned place preference and nucleus accumbens dopamine release in the rat. Synapse 46:83-90. CrossRef Medline

Stuber GD, Klanker M, de Ridder B, Bowers MS, Joosten RN, Feenstra MG, Bonci A (2008) Reward-predictive cues enhance excitatory synaptic strength onto midbrain dopamine neurons. Science 321:1690-1692. CrossRef Medline

Suaud-Chagny MF, Chergui K, Chouvet G, Gonon F (1992) Relationship between dopamine release in the rat nucleus accumbens and the discharge activity of dopaminergic neurons during local in vivo application of amino acids in the ventral tegmental area. Neuroscience 49:63-72. CrossRef Medline

Szczypka MS, Kwok K, Brot MD, Marck BT, Matsumoto AM, Donahue BA, Palmiter RD (2001) Dopamine production in the caudate putamen restores feeding in dopamine-deficient mice. Neuron 30:819-828. CrossRef Medline

Thanos PK, Ramalhete RC, Michaelides M, Piyis YK, Wang GJ, Volkow ND (2008) Leptin receptor deficiency is associated with upregulation of cannabinoid 1 receptors in limbic brain regions. Synapse 62:637-642. CrossRef Medline

Ungless MA, Whistler JL, Malenka RC, Bonci A (2001) Single cocaine exposure in vivo induces long-term potentiation in dopamine neurons. Nature 411:583-587. CrossRef Medline

Ungless MA, Magill PJ, Bolam JP (2004) Uniform inhibition of dopamine neurons in the ventral tegmental area by aversive stimuli. Science 303: 2040-2042. CrossRef Medline

Wanat MJ, Willuhn I, Clark JJ, Phillips PE (2009) Phasic dopamine release in appetitive behaviors and drug addiction. Curr Drug Abuse Rev 2:195213. CrossRef Medline

Westerink BH, Teisman A, de Vries JB (1994) Increase in dopamine release from the nucleus accumbens in response to feeding: a model to study interactions between drugs and naturally activated dopaminergic neurons in the rat brain. Naunyn Schmiedebergs Arch Pharmacol 349:230-235. Medline

Wise RA (2004) Dopamine, learning and motivation. Nat Rev Neurosci 5:483-494. CrossRef Medline

Wolfart J, Roeper J (2002) Selective coupling of T-type calcium channels to SK potassium channels prevents intrinsic bursting in dopaminergic midbrain neurons. J Neurosci 22:3404-3413. Medline

Zhen J, Reith ME, Carr KD (2006) Chronic food restriction and dopamine transporter function in rat striatum. Brain Res 1082:98-101. CrossRef Medline

Zweifel LS, Parker JG, Lobb CJ, Rainwater A, Wall VZ, Fadok JP, Darvas M, Kim MJ, Mizumori SJ, Paladini CA, Phillips PE, Palmiter RD (2009) Disruption of NMDAR-dependent burst firing by dopamine neurons provides selective assessment of phasic dopamine-dependent behavior. Proc Natl Acad Sci U S A 106:7281-7288. CrossRef Medline 